\title{
The Role of Accounting and the Debate between Historical Cost and Fair Value
}

\author{
${ }^{1}$ Associate Professor of Accounting, McDonough School of Business, Georgetown University, Washington, DC 20057-0004, \\ USA, E-mail:wt29@georgetown.edu
}

\begin{abstract}
:
This article argues that the debate between historical cost basis and fair value basis of accounting also rests upon one central question: what kinds of output do users want out of the accounting system: metrics to measure the long-run profit-generating ability or metrics to capture the short-run fluctuation in the estimated values of net assets?
\end{abstract}

Keywords: fair value approach, historical cost

DOI: 10.1515/ael-2016-0066

On the Evolutionary Advantage of Cost Accounting and Conservatism

1 Braun, E. (2016). The Ecological Rationality of Historical Costs and Conservatism. doi: https: / / doi.org/10.1515/ael-2015-0013.

2 Basu, S. \& Waymire, G. (2017). Historical Cost and Conservatism Are Joint Adaptations That Help Identify Opportunity Cost. doi: https:/ /doi.org/10.1515/ael-2016-0070.

3 Saito, S. \& Fukui, Y. (2016). Whither the Concept of Income? doi: https://doi.org/10.1515/ael-2016-0013.

4 Tang, V. (2017). The Role of Accounting and the Debate between Historical Cost and Fair Value. doi: https:/ / doi.org/10.1515/ael-2016-0066.

5 Baker, C. (2016). Commentary on Braun's “The Ecological Rationality of Historical Costs and Conservatism" doi: https:/ /doi.org/10.1515/ael-2016-0066.

6 Braun, E. (2017). Concluding Remarks on the Symposium on the Evolutionary Advantage of Cost Accounting and Conservatism. doi: https://doi.org/10.1515/ael-2017-0049.

Braun's piece explores the ecological foundation for the historical cost basis for measuring assets and liabilities. Braun (2016) brings up discussions on some contentious but thought-provoking questions. It finds that the historical-cost basis of accounting is rooted in behavioral economics. In this brief commentary, I argue that the debate on historical-cost basis versus fair-value basis of accounting also rests upon the question of what role accounting should serve. The goal here is not to influence the gist of Braun (2016) but rather provide an additional perspective that also sheds some light on the debate.

The first question in mind is whether the debate on historical-cost basis versus fair-value basis of accounting is economically meaningful to a broad audience rather than standard setters themselves. Someone may go as far as drawing an analogy between this debate between historical-cost basis and fair-value basis and the two competing systems to measure temperature. It is certainly the same when everyone switches from measuring temperature in Celsius to measuring it in Fahrenheit. Similarly, some may argue, as long as the same set of accounting standards are applied unanimously to all companies and consistently from time to time to ensure comparability and consistency, historical-cost basis is no different from fair-value basis in its economic implications.

At the center of this debate lies the philosophical question of what role should accounting serve now and in the future. Under the classical principle-agent framework, accounting primarily resolves the principle-agent problem in corporations. This primary role of accounting is achieved by bookkeeping to safeguard the company's assets and by providing periodic information to help decision makers to both value the company and evaluate the performance of the company to facilitate monitoring.

The choice between the historical cost basis and fair value basis centers around the decision on what is the proper reference point. Under the fair value framework, the asset position at the beginning of the period serves as the reference point. Under the historical cost framework, the original amount of money that has been paid

Vicki Wei Tang is the corresponding author.

(c) 2019 Walter de Gruyter $\mathrm{CmbH}$, Berlin/Boston.

This content is free. 
for the firms' assets serves as the reference point. Given the various functions that accounting serves, in my view, what is the proper reference point depends on the specific function that accounting is supposed to serve.

If the function is simply to provide periodic information to value the company and the related claims, the asset/liabilities position at the beginning of the period is certainly the proper benchmark, and therefore, the fair-value basis of accounting is more advantageous to serve this function.

If accounting's function is to safeguard the company's assets, the original amount of money that has been paid for the firms' assets is certainly the proper benchmark, and therefore, the historical-cost basis of accounting is more advantageous to serve this function.

If accounting's function is to provide periodic information to evaluate the performance of the company and the management team in charge, the original amount of money that has been paid for the firms' assets is certainly the proper benchmark. This is because "wealth" construction or destruction through the production and marketing functions of the firm is typically measured relative to the original amount of money that has been paid for the firm's assets (Littleton 1953). Accordingly, the historical-cost basis of accounting is more advantageous to serve the function of monitoring the performance of the management team and the company.

It is reasonable to argue that, if the objective of accounting is to provide periodic information to evaluate the performance of the company in the capital market, the asset/liabilities position at the beginning of the period is certainly the proper benchmark. However, when stocks or bonds are publicly traded, alternative measures to evaluate the performance of the company in the capital market are easily available in a much more timely manner. Fair-value based accounting only summarizes firm-level information provided by the market. Therefore, the incremental information provided by accounting to evaluate the performance of the company in the capital market seems to be rather limited, if not redundant (Bensimhon \& Biondi, 2013). However, the need for accounting to provide information that is beyond the market information is especially salient in public companies because of its diffused share ownership, and thus, its greater need to monitor the performance of the company and the management team.

In my view, the debate on historical cost versus fair value basis of measuring assets and liabilities is parallel to the "Celsius versus Fahrenheit" distinction only if both of the following assumptions hold. The first assumption is that accounting standards do not alter firm and managerial behavior and the second assumption is that the capital market sees through the accounting conventions and complication of measuring firm performance.

Let us first discuss the implication of market efficiency paradigm on this debate between historical cost basis and fair value basis for accounting. In its strong form, market efficiency assumes that the market fully sees through the accounting conventions and complication of measuring firm performance, including unraveling manipulated accounting numbers. If the assumption holds, it really does not matter whether we use historical cost basis for accounting or adopt fair value basis for accounting. However, the usefulness of fundamental analysis, which examines whether and how our knowledge of accounting yields superior insights into firm performance and security valuation, suggests that such an assumption is likely to be violated under many circumstances. Biondi (2011) makes a related point that the implicit assumptions of both perfect markets and complete contracts underlie the validity of fair-value based accounting.

Second, let us discuss the validity of the assumption that accounting standards do not alter firm and managerial behavior. Bountiful theoretical and empirical studies suggest that managers engage in earnings management and in real activities management that influence the reported financial statements (see Dechow, Ge, \& Schrand, 2010 for a comprehensive review). Under the historical cost basis of accounting, net income measures the excess of revenue over expenses, both of which are measured on the basis of historical costs. And, the excess of revenue over expenses adds to net assets of the company on the balance sheet. Income statement is the prime financial statement, and balance sheet is the derived item. The management needs a partner in crime to manipulate revenue and cash flows. Therefore, manipulation of revenues and expenses as reported on the prime income statement under historical cost basis is somehow bounded (Ijiri 1967).

In contrast, under the fair-value based accounting, balance sheet becomes the prime financial statement and net income is only the derived item from the difference in the value of net assets. The fair value approach is likely to sway managerial reporting objectives from reporting highest possible sales and lowest possible expenses to reporting highest possible assets and lowest possible liabilities. The management team does not need a partner in crime to manipulate the value of assets and liabilities as reported on the prime balance sheet. The situation is especially salient for Level 2 and Level 3 assets and liabilities under fair-value applications because all it requires is to alter the set of assumptions and/or applied models. There is no systematic boundary to manipulation of assets and liabilities. If the quality of reported assets and liabilities is so easily tempered, the derived net income becomes easily tempered as well. Imagine the extreme case of a financial institution whose assets and liabilities are predominately Level-2 and Level-3 financial instruments, the derived net income under fair value approach could be manufactured from thin air.

Furthermore, accounting rules are of great importance because the mandatory supervisory ratios and reports imposed on financial institutions are largely based on accounting data (Schwarz et al., 2015). Under the 
fair value basis, the immediate recognition of losses in economic downturns leads to a deterioration in some of the supervisory ratios and banks may be forced to sell assets at fire-sale prices. Conversely, the immediate recognition of gains in economic booms leads to an improvement in some of the supervisory ratios and banks could expand lending or buy more assets, which pushes up the price of assets even further. Fair value accounting coupled with other factors, such as regulatory and collateral requirements, induces unnecessary market volatility into reported assets/liabilities and the derived net income (Biondi 2015). For instance, Dichev and Tang (2008) documents a marked increase in the volatility of reported earnings and a deteriorated matching between revenue and expenses as a result of FASB's deliberate move away from income statement (historical cost) approach of accounting to balance sheet (fair value) approach of accounting. Moreover, many if not most of derivative instruments are the offspring of accounting standards, designed by financial engineers to get around the existing constraints imposed by FAS133 (Sunder 2011).

To summarize, the relative importance of the various functions that accounting serve in the economy broadly define whether historical cost basis or fair value basis is more advantageous. As long as accounting continues to serve its role as mitigating the principle-agent conflict between shareholders and managers, historical cost basis is here to stay. Moreover, if accounting is aspired to provide new information beyond the firm-level information provided by the market and finds it unique position in the economy, historical cost basis facilitates the achievement of such an aspiration. To conclude, eventually the debate between historical cost basis and fair-value approach all boils down to what kind of output do we want out of the accounting system: measures of long-run profit-generating ability or measures of short-run fluctuation in the estimated value of net assets?

\section{References}

Bensimhon, L., \& Biondi, Y. (2013). Financial bubbles, common knowledge and alternative accounting regimes: An experimental analysis of artificial spot security markets. Accounting for or from the market? The Japanese Accounting Review,3,21-59.

Biondi, Y. (2011). The pure logic of accounting: A critique of the fair value revolution. Accounting, Economics, and Law: A Convivium,1(1),7.

Biondi, Y. (2015). Accounting and the formation of share market prices over time: A mathematical institutional economic analysis through simulation and experiment. Applied Economics,47(34-35),3651-3672.

Braun, E. (2016). The ecological rationality of historical costs and conservatism. Accounting, Economics and Law: A Convivium, .. forthcoming. DOI: 10.1515/ael-2015-0013.

Ijiri, Y. (1967). The foundations of accounting measurement: A mathematical, economic and behavioral inquiry. Englewood Cliffs, N]: Prentice-Hall.

Dechow, P., Ce, W., \& Schrand, C. (2010). Understanding earnings quality: A review of the proxies, their determinants and their consequences. Journal of Accounting and Economics,50(2),344-401.

Dichev, I. D., \& Tang, V. W. (2008). Matching and the changing properties of accounting earnings over the Last 40 Years. The Accounting Review,83(6),1425-1460.

Littleton, A. C. (1953). Structure of accounting theory. Sarasota (FL): AAA.

Schwarz, C., Karakitsos, P., Merriman, N., \& Studener, W. (2015). Why accounting matters: A central bank perspective. Accounting, Economics and Law: A Convivium, 5(1),1-42.

Sunder, S. (2011). Imagined worlds of accounting. Accounting, Economics, and Law: A Convivium, 1(1),8. 